\title{
06.01.00 MIPOHIOMULi
}

\section{ПРОИЗВОДСТВЕННЫЙ ПОТЕНЦИАЛ ЗЕРНОВОГО СОРГО В СЕВЕРНОЙ ЗОНЕ СОРГОСЕЯНИЯ}

Антимонов Александр Константинович, кандидат сельскохозяйственных наук, заведующий лабораторией селекции и семеноводства крупяных и сорговых культур

Сыркина Любовь Федоровна, кандидат сельскохозяйственных наук, ведущий научный сотрудник лаборатории селекции и семеноводства крупяных и сорговых культур

Антимонова Ольга Николаевна, кандидат сельскохозяйственных наук, старший научный сотрудник лаборатории селекции и семеноводства крупяных и сорговых культур

Федеральное государственное бюджетное научное учреждение «Поволжский научноисследовательский институт селекции и семеноводства имени П.Н. Константинова» (ФГБНУ «Поволжский НИИСС»)

446442, Самарская обл., г. Кинель, пгт. Усть-Кинельский, ул. Шоссейная 7; тел.: 8846(63)46-243, e-mail: antimonov.63@mail.ru

Ключевые слова: сорго, сорт, испытание, урожайность, зерно, норма высева.

Целью исследованийявляется информационная активность по результатам внедрения в производство зерновых сортов сорго для целевого использования. В 2005 году сорт Премьера прошел производственное испытание в КФХ «Василина» Большечерниговского района на площади 10 га. Урожайность зерна - 1,94 m/2a. В 2009 году сорт сорго Славянка был посеян в ООО «Юг Поволжья» на площади 8 га. Получено 0,75 m/га при урожайности ячменя 0,30 m/2a. В 2010 году сорт Славянка высевался на 175 га, сформировал урожайность зерна 1,35 m/2а, при урожайности ячменя 0,2 m/га. В КХ «Шанс» Борского района сорт Славянка высевался в 2009 году на 20 га, в 2010 году - 30 га. Получили урожаи зерна: 1,43 m/га в 2009 году и 1,24 m/га в 2010 году, при средней урожайности ячменя соответственно 0,97 и 0,52 m/га. В ФГУП ЦСКБ «Прогресс» Богатовского района сорт Славянка сеяли в 2013 году на площади 700 га. Урожайность зерна -1,52 m/га при средней урожайности ячменя в хозяйстве 0,50 m/га. В 2016 году сорт сорго Рось был посеян в ИП «КФХ Каманин Н.М.» Несттегорского района на 100 га. Урожайность зерна - 2,0 m/га, при средней урожайности ячменя в хозяйстве $1,7 \mathrm{~m} / 2 а$. В СПК «им. Ленина» Белявского района этого же года урожайность сорго Рось со 1100 га составила $1,3 \mathrm{~m} / 2 a$, ячменя - 0,9 m/2а. Считаем, что внедрение зернового сорго в производство позволит стабильно получать фуражное зерно в любых засушливых и острозасушливых погодных условиях.

\section{Введение}

Особенностью земледелия Самарской области является недостаток влаги в почве в большинстве районов за период вегетации растений. Причем, такой антициклональный тип погоды характеризуется нарастанием повторяемости экстремально высоких температур воздуха и малого количества выпавших осадков. Традиционным зернофуражным культурам тяжело формировать полноценный урожай в таких условиях, поэтому решающее значение отведено пра- вильному подбору кормовых культур, обеспечивающих значительную отдачу с каждого гектара посева даже в засуху . Весьма достойное место среди таких культур по праву должно быть отдано зерновому сорго, обладающему высоким потенциалом полезности за счет своей неприхотливости и кормовой ценности, способного при любых погодных условиях формировать высокий урожай [1, 2, 3, 4, 5, 6, 7].

Зерновое сорго, наряду с высокой засухоустойчивостью, имеет высокую питательную 


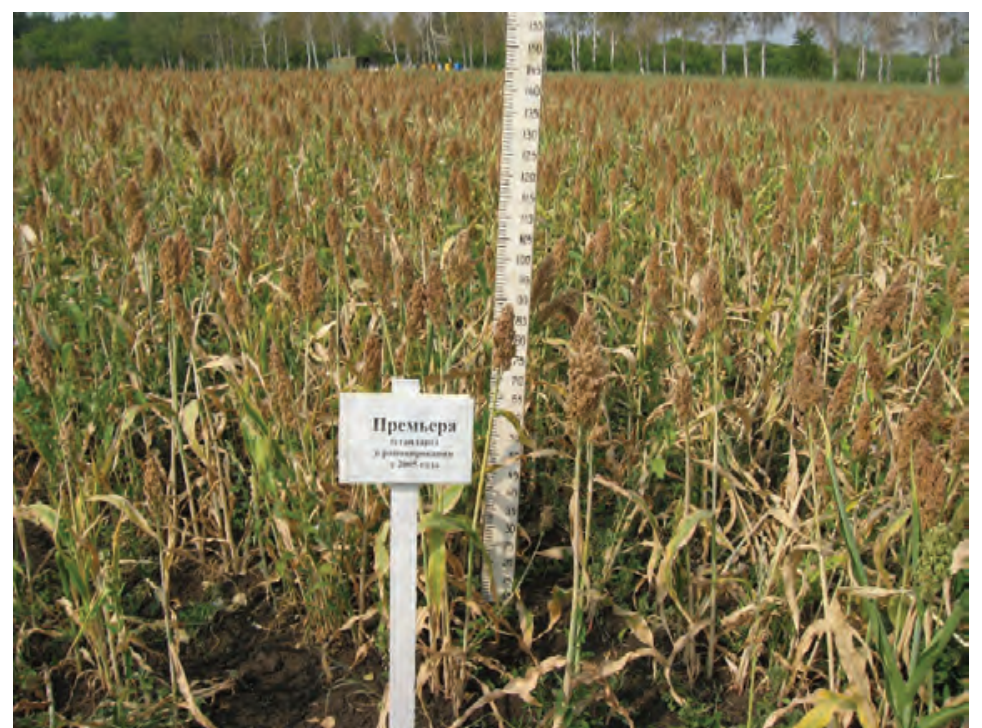

Рис. 1 - Сорго зерновое Премьера

ценность как кормовая культура и является хорошим концентрированным кормом для всех видов скота, птицы, рыбы. Оно содержит 70-75\% крахмала, 9-15\% -протеина, 3,5\% -жира. В 100 кг зерна содержится 118-120 кг кормовых единиц. В зерне находятся 17 незаменимых аминокислот, витамины (E1, B1, B2, В3, каротин), минеральные вещества (P2O5, K2O и MgO), танины (дубильные вещества), по своему действию являющиеся аналогами витамина $\mathrm{P}$, так как укрепляют стенки кровеносных сосудов [8, 9, 10, 11, $12,13]$. Оценка эффективности использования зернового сорго сорта Рось в составе комбикормов-концентратов для лактирующих коров была проведена в СПК «Заветы Ленина» Нефтегорского района Самарской области. Из сформированных трех групп коров по 8 голов в каждой по принципу аналогов с учётом возраста, сроков отёла, продуктивности продолжительность учетного периода (кормления) составила 100 дней. По результатам исследований установлено, что общий удой молока натуральной жирности за учётный период у коров II и III опытных групп превышал контроль на 89-169 кг или на 3,1-5,9\%. Выше у них по сравнению с контролем было и содержание жира и белка соответственно на 0,05-0,07; 0,19-0,21 абс.\%, вследствие чего среднесуточный удой молока 4\% жирности у коров II и III опытных групп превышал контроль на 1,2-2,1 кг или на 4,4-7,9\%. Включение в состав комбикормов-концентратов для новотельных лактирующих коров зернового сорго обеспечивает повышение переваримости питательных веществ рациона и сопровождается ростом молочной продуктивности. При этом экономически целесообразно включать 40,0 \% зернового сорго в состав комбикорма-концентрата для лактирующих коров. [14, 15].

В рамках государственного задания на протяжении 25 лет селекционеры ФГБНУ «Поволжский НИИСС» ведут успешную работу по созданию надежно вызревающих в условиях Среднего Поволжья сортов зернового сорго, способных обеспечить стабильный по годам урожай разного направления использования: фураж, монокорм, силос. На сегодняшний день внесены в Государственный реестр сельскохозяйственных растений, допущенных к использованию, сорта: Премьера (2004 г.), Славянка (2011 г.), Рось (2012 г.). Но создание очередного сорта любой культуры не является завершающим этапом в работе селекционера. Дальнейшая задача состоит в испытании сортов непосредственно в производственных условиях, где выявляется его потенциал и пригодность для полностью механизированных условий возделывания. Важно, чтобы сорт был признан сельхозтоваропроизводителями, востребован в производстве и занял свою «нишу» в том или ином регионе или области. На сегодняшний день востребованность этой культуры в нашем регионе оставляет желать лучшего в силу разных факторов: отсутствия достаточной информации, нерешительности производителей, дефицита семян и др.

Целью наших исследований является информационная активность по характеристике и потенциальным возможностям сортов зернового сорго, районированных в 7 (Средневолжском) и 9 (Уральском) регионах, и результатам внедрения в производство этих сортов для целевого использования.

\section{Объекты и методы исследований}

Изучение сортов зернового сорго проводилось в производственных условиях в КФХ «Василина» Большечерниговского района, КX "Шанс» Борского района Самарской области в 2009, 2010 гг., ООО «Юг Поволжья» Большеглушицкого района в 2009 году, СПК «Мирошкино» Первомайского района Оренбургской области в 2013 г., ФГУП ЦСКБ «Прогресс» Богатовского района Самарской области в 2013 г., ИП «КФХ Каманин Н.М.» Нефтегорского района в 2016 г., СПК «им. Ленина» Белявского района Оренбургской области в 2016 г., ООО «Агропромышленная компания Комсомолец» в 2017 г.

Посев зернового сорго проводили в оптимальные сроки сплошным рядовым способом. Уход за посевами осуществляли по общеприня- 
той технологии для лесостепной зоны Среднего Поволжья и Южного Урала. Все результаты исследований подтверждены Актами внедрения научно-исследовательской работы.

Сорт Премьера - раннеспелый, с вегетационным периодом 76-100 дней. Низкорослый, высотой до 120 см. Устойчив к полеганию, ломкости стеблей и метелок при перестое, имеет сочную сердцевину стебля. Урожайность зерна -от 2,0 до 4,4 т/га. В зерне сорта Премьера содержится 9 - 11\% сырого протеина, 74\% -крахмала, 4\% -жира. К тому же, с 1 га посева можно дополнительно получить до 100-150 ц сочных стеблей, содержащих до 9\% сахаров. Использование: фуражное зерно и монокорм, приготовление концентрированного силоса для всех видов животных и птицы (рис. 1).

Сорт Славянка - раннеспелый, вегетационный период - 72-95 дней. Низкорослый (до 110 см), тонко- и сухостебельный. Доля метёлок в общей биомассе до 57\%. Урожайность зернадо 4,4 т/га. В зерне содержится 10 - 14\% сырого протеина, 83\% БЭВ и 6\% жира. Использование: фуражное зерно (рис. 2).

Сорт Рось -раннеспелый. Вегетационный период -87-100 дней. Растения низкорослые, от 120 до 143 см, выровненные по высоте, слабо кустящиеся. Стебель тонкий (8-11 мм), малооблиственный (6-8 листьев) с сухой сердцевиной. Урожайность зерна -от 2,0 до 5,3 т/га. В зерне содержится 10 - 11 \% сырого протеина, 80 - 82 \% БЭВ и 4 - 5 \% жира. Устойчив к пониженным температурам в послевсходовый период и к засухе - в период вегетации. Использование: на кормовые (фуражное зерно) и пищевые (получение крахмала и спирта) цели (рис. 3).

\section{Результаты исследований}

Технология возделывания зернового сорго мало отличается от выращивания традиционных кормовых культур, но семеноводство наших сортов в северной зоне соргосеяния гарантирует получение семян высоких категорий.

В 2004 году был районирован первый сорт Премьера по 7 регионам. В 2005 году он прошел производственное испытание в КФХ «Василина» Большечерниговского района под научно-технической разработкой «Изучение культуры зернового сорго Премьера в условиях сухой степи Большечерниговского района» с 19 мая по 5 сентября на площади 10 га. Способ посева- сплошной рядовой. Норма высева семян- 20 кг/га. В процессе внедрения выполнены работы по учету общей биомассы растений и урожая зерна. Учет

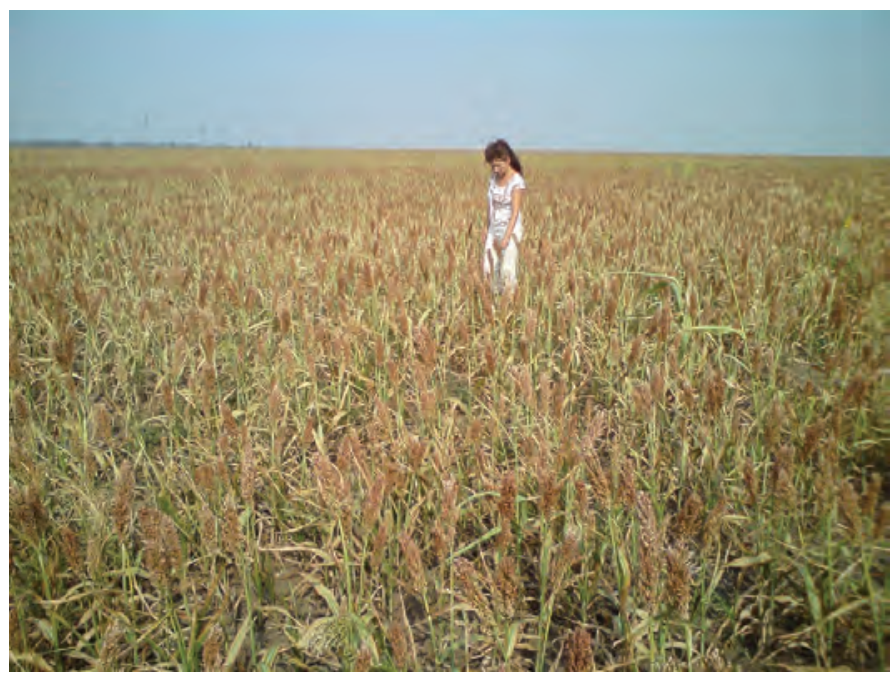

Рис. 2 - Сорго зерновое Славянка (Большечерниговский р - Он, ООО «Юг Поволжья», 2010 г.)

урожая показал, что общая биомасса растений составила 8,2 т/га, урожайность зерна - 1,94 т/га.

В 2009 году новый сорт зернового сорго Славянка был посеян в ООО «Юг Поволжья» на площади 8 га. Предшественник - яровая пшеница. Основная обработка почвы - отвальная. Посев проведен 28 мая сеялкой АУП-18.05. Посеву предшествовала одна культивация на глубину заделки семян - 5-7 см. Способ посева - сплошной рядовой, норма высева - 0,8 млн. всхожих зерен на 1 га, весовая - 20 кг.

Несмотря на очень жёсткие условия вегетационного периода (за лето не выпало ни одного дождя), с каждого гектара посева зернового сорго было получено по 7,5 ц кондиционных семян, при урожайности ячменя 3,0 ц/га.

В 2010 году сорт зернового сорго Славянка в данном хозяйстве занимал площадь посева 175 га. Предшественник - кукуруза на силос. Осенью была проведена поверхностная обработка почвы - дисковое лущение стерни (БДМ6) на глубину 10-12 см. Семена перед посевом обработали «Премиксом-200». Посев проведен 23 мая сеялкой АУП-18.05 вразброс (сплошной посев) на глубину 5-6 см. 20 августа сорго скосили в валки, через 4 дня (24 августа) обмолотили комбайном Дон-1500. Влажность зерна после обмолота валков составила 13,5\%.

В условиях невиданной засухи данного вегетационного периода (ГТК за июнь - август = 0,1, сумма активных температур за этот же период превысила среднемноголетнее значение на $500^{\circ} \mathrm{C}$ ) новый сорт зернового сорго Славянка за 80 дней вегетации смог сформировать достаточно высокий урожай зерна - 1,35 т/га, при урожайности ячменя в хозяйстве 0,2 т/га. 
При стоимости 1 т семян ячменя 6 тыс. рублей и сорго зернового 10 тыс. руб. (в ценах на весну 2010 г.) и норме высева семян ячменя 200 кг/га и сорго 20 кг/га общая экономическая эффективность составит:

- на 1 га - 7,9 тыс. руб.

- на 175 га - 1 382, 5 тыс. руб.

Производственное испытание зернового сорго Славянка в КХ «Шанс» Борского района Самарской области в 2009-2010 гг. показало также хорошие результаты. Сорт высевался в данном хозяйстве в 2009 году на площади 20 га и в 2010 году - 30 га по предшественнику яровая пшеница. Технология возделывания - ресурсосберегающая. Основная обработка почвы -безотвальная стерневым культиватором “Смарагд - 9/400» на глубину 14-15 см. Весенняя обработка почвы в 2009 году складывалась из ранневесеннего боронования средними зубовыми боронами БЗСС-1,0 и одной культивации широкозахватным агрегатом ОПО-4,25 на глубину 8-10 см с последующим прикатыванием кольчатыми катками ЗККШ-6А. В 2010 году культивация не проводилась ввиду значительного иссушения почвы к моменту посева. Посев - сплошной сеялкой АУП-18.05. Срок посева - 27 мая в 2009, и 25 мая - в 2010 году. Норма высева-0,8 млн. всхожих семян на 1 га, весовая 20-22 кг/га. После посева поле прикатывали кольчатыми катками.

Уборка на зерно - раздельная с использованием жатки ЖВН-6 для скашивания и комбайна Енисей-950 для подбора и обмолота валков. Ввиду того, что у сорта Славянка соломина тонкая и сухая, валки просыхали за 4-5 дней, и влажность

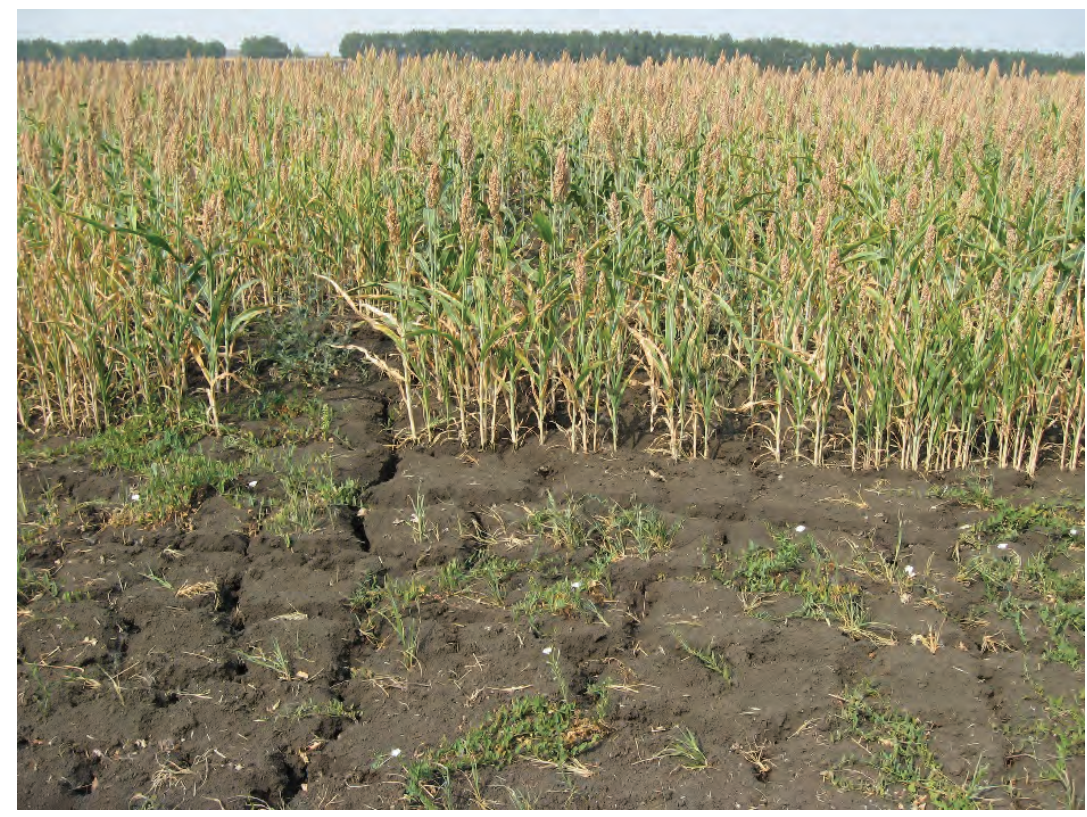

Рис. 3 - Сорго зерновое Рось убранного зерна не превышала $14 \%$.

В крайне засушливых условиях вегетационных периодов 2009, и особенно 2010 гг., новый сорт зернового сорго Славянка сформировал значительные урожаи зерна: 1,43 т/га в 2009 году и 1,24 т/га в 2010 году, при средней урожайности ячменя в хозяйстве соответственно 0,97 и 0,52 т/га.

Производственное испытание сорта Славянка проводили в ФГУП ЦСКБ «Прогресс» Богатовского района Самарской области в 2013 году на площади 700 га. Предшественник - ячмень. Осенняя обработка почвы -отвальная. Посеву предшествовали две разноглубинные культивации культиватором КПС-4 с одновременным прикатыванием почвы. Посев проведен 15 мая сплошным способом с нормой высева 0,8 млн. всх. семян на 1 га трёхсеялочным агрегатом С3П-3,6. В фазе 5 - 6 листьев растений сорго провели обработку посевов гербицидом «Октапон» в дозе 0,6-0,7 кг. д. в. В фазу восковой спелости зерна (после 15 августа) провели десикацию посевов гербицидом сплошного действии «Тотал, ВР» в дозе 3 кг/га и с 10 сентября приступили к уборке зерна сорго напрямую комбайном Енисей-1200.

Урожайность зерна сорго зернового Славянка составила 1,52 т/га при средней урожайности ячменя в хозяйстве 0,50 т/га. От разницы затрат на семена ячменя и сорго и от прибавки урожайности зерна сорго общая экономическая эффективность составила на 1 га - 9,928 тыс. руб., на 700 га - 6949,6 тыс. руб.

В 2013 году в СПК «Мирошкино» Первомайского района Оренбургской области производственное испытание проходили три сорта под научно-технической разработкой «Новые сорта зернового сорго: Премьера, Славянка и Рось в степной зоне Южного Урала» с 11 мая по 30 сентября на площади 27 га, 30 га и 10 га соответственно. Предшественник- озимая пшеница, высеваемая на фураж. Почвы -легкие супесчаные. С осени была проведена обработка почвы глубокорыхлителем ГР-4,3. Весной -одна культивация перед посевом широкозахватным культиватором КШУ-4 на глубину заделки семян. Посев - сплошной с нормой высева 0,8 млн. всхожих семян на 1 га проведен 20 мая сеялкой СЗС-2,1. До всходов (через 3 дня после посева) провели «слепое» боронование в 1 след лёгкими боронами. Уборка на 
зерно -раздельная с использованием жатки ЖВП6.4. Валки подбирали и обмолачивали комбайном Нива -эффект. Урожайность зерна составила: Премьера - 1,9 т/га, Славянка - 1,84 т/га, Рось 2,07 т/га при урожайности озимой пшеницы 0,62 т/га. Общая экономическая эффективность на 1 га составила: Премьера - 11,56 тыс. руб., Славянка 10,72 тыс. руб., Рось - 12,10 тыс. руб.

В 2016 году сорт зернового сорго Рось был посеян в ИП «КФХ Каманин Н.М.» Нефтегорского района Самарской области на площади 100 га. Предшественник - яровая пшеница. Осенняя обработка почвы- безотвальная с использованием широкозахватного культиватора КПШ-8. Весной провели боронование агрегатом КБМ-4,2. Посев проведен 17 мая сплошным способом (вразброс) сеялкой АУП - 18.05 с нормой высева 0,8 млн. всхожих зерен на 1 га (20 кг). Уборка на зерно - раздельная: 20 августа сорго скосили в валки, 27 августа -обмолотили комбайном Нива Полесья. После обмолота валков зерно имело влажность 12,8\%. Вегетационный период сорта Рось составил 88 дней. Урожайность зерна - 2,0 т/га, при средней урожайности ячменя в хозяйстве 1,7 т/га. Экономическая эффективность от использования сорго зернового Рось составила 5 тыс.руб. на 1 га

В СПК «им. Ленина» Белявского района Оренбургской области этого же года в условиях почти полного отсутствия осадков в июне-июле урожайность зернового сорго Рось с площади 1100 га составила 1,3 т/га, ячменя - 0,9 т/га. Только от разницы затрат на семена ячменя и сорго и от прибавки урожайности зерна сорго в 0,4 т/га эффективность использования зернового сорго Рось составила 5,8 тыс. руб на 1 га.

В ООО «Агропромышленная компания Комсомолец» Кинельского района в 2017 г. проходил испытание сорт Рось на площади 7 га. Осенняя обработка почвы - отвальная, на глубину 2527 см плугом ПЛн-6-35. Весной было проведено покровное боронование. Предпосевная культивация - КПС-4 на глубину заделки семян. Посев проведен 25 мая сплошным рядовым способом сеялкой С3-3,6 с нормой высева 0,8 млн. всхожих зерен на 1 га (20 кг). Предшественник - яровая пшеница. Уборка на семена -раздельная: 1 сентября сорго скосили в валки, 7 сентября обмолотили комбайном Нива Полесья. Вегетационный период сорта Рось составил 85 дней. Урожайность зерна - 2,5 т/га при средней урожайности ячменя в хозяйстве 2,1 т/га. Общая экономическая эффективность составила на 1 га -5,0 тыс. руб.

Выводы

На основании производственного испыта- ния в разные годы считаем, что внедрение зернового сорго в производство позволит стабильно получать фуражное зерно в любых засушливых и острозасушливых погодных условиях. Товаропроизводители хозяйств разных форм собственности уже по достоинству оценили эту культуру.

\section{Библиографический список}

1. Зерновое сорго - стабилизатор урожая фуражного зерна в засушливой зоне Среднего Поволжья / А.К. Антимонов, Л.Ф. Сыркина, О.Н. Антимонова, Е.В. Матвиенко, В.Я. Гаврилина // Научное обеспечение селекции и семеноводства сельскохозяйственных культур в Поволжском регионе. Материалы Всероссийской научно-практической конференции. - Самара, 2013. - С. 66-70.

2. Румянцев, А.В. Культура сорго в решении проблемы засухи и экономической стабильности сельского хозяйства в условиях Поволжского региона и Урала / А.В. Румянцев, В.В. Глуховцев // Известия Оренбургского государственного аграрного университета. - 2014. - № 2 (46). - С. 46-49.

3. Горбунов, В.С. Сорго - универсальная кормовая и техническая культура сухих степей и полупустынь Российской Федерации / В.С. Горбунов, А.Г. Ишин, Г.И. Костина. - Саратов, 2008. - 66 с.

3. Шепель, Н.А. Селекция и семеноводство гибридного сорго / Н.А. Шепель. - Ростов-наДону: изд-во РГУ, 1985. - 256 с.

4. Большаков Александр Захарович. Агроэкологическое обоснование возделывания и использования сорго в Центрально-Черноземном регионе Российской Федерации: автореф. дис. ... канд. с.-х. наук: 06.01.09 / А.З. Большаков. - Воронеж, 2003. - 20 c.

5. Ворников, Д.В. Формирование агрофитоценозов полевых культур в степной зоне Среднего Поволжья / Д.В. Ворников, Г.И. Баздырев, А.А. Павликов // Известия ТСХА. - 2010. - №6. - С. 7-10.

6. Stapf, O. Sorghum / O. Stapf // in: Flora of Tropical Africa. London. - 1917. -V. 9. - P. 104-154.

7. Eastin, I.D. Water and temperature effects on sorghum and millet as related to grain production and breeding. Annu. Rep. - Sorghum-millet collaborative research support program. - 1988. P.48-54.

8. Морозов, Е.В. Адаптивная технология возделывания - ключ к расширению посевов зернового сорго в Поволжье / Е.В. Морозов, А.И. Заварзин, Ю.И. Суминов // Современные технологии возделывания сельскохозяйственных культур: сборник научных статей СГАУ им. Н.И. Вавилова. - Саратов: Изд-во СГАУ им. Н.И. Вавилова, 2003. - C. 154-159. 
9. Биленко, П.Я. Сорго в одновидовых и смешанных посевах / П.Я. Биленко, Я. Шевников // Кормопроизводство. - 1985. - № 12. - С. 30-31.

10. Морозов, Е.В. Народно-хозяйственное значение сорговых культур / Е.В. Морозов, А.Г. Субботин, Н.Н. Сафонова // Аграрные конференции. - 2017. - № 1. - С. 30-32.

11. Алабушев, А.В. Сорго зерновое - перспективное сырье для производства крахмала / А.В. Алабушев, В.В. Ковтунов, О.А. Лушпина // Достижения науки и техники АПК. - 2016. - Том 30, № 7. - С. 64-66.

12. Царёв, А.П. Новые сорта сорго - дополнительный резерв получения фуражного зерна и крупы в Поволжье / А.П. Царёв, Г.И. Костина, Т.Г.
Хуспятдинова // Кукуруза и сорго. - 2001. - №1. - С. 20-21.

13. Сорго в кормлении животных и птиц / Н.А. Ковтунова, В.В. Ковтунов, С.И. Горпиниченко, Г.М. Ермолина // Фермер. Поволжье. - 2017. - № 4 (57). - С. 51-53.

14. Зерновое сорго сорта Рось в рационах животных и птицы / В.С. Зотеев, Г.А. Симонов, С.В. Зотеев, А.Г. Симонов, В.С. Никульников // Эффективное животноводство. - 2017. - № 9 (139). - С. 28-30.

15. Зерновое сорго в комбикормах для цыплят-бройлеров / С.В. Зотеев, В.С. Зотеев, Г.А. Симонов, В.В. Мухранов // Птицеводство. - 2017. - № 6. - С. 27-29.

\title{
PRODUCTION POTENTIAL OF GRAIN SORGHUM IN THE NORTHERN ZONE OF SORGHUM PLANTING
}

\author{
Antimonov A.K., Syrkina L.F., Antimonova O.N. \\ Federal State Budgetary Scientific Institution "Volga Research Institute of \\ Selection and Seed Production named after P.N. Konstantinov" \\ 446442, Samara region, Kinel town, Ust-Kinelsky v., Shosseinaya st. 7; \\ tel .: 8846 (63) 46-2-43, e-mail: antimonov.63@mail.ru
}

Keywords: sorghum, variety, testing, yield, grain, seeding amount.

The aim of the research is informational activity based on the results of introduction into production of sorghum grain varieties for targeted use. In 2005, Premiera variety passed production testing in Vasilina farm in Bolshechernigovsky district on an area of 10 hectares. The grain yield was $1.94 t$ / ha in 2009 , the sorghum variety Slavyanka was sown in 000 "Yug Povolzhiya" on an area of 8 hectares. $0.75 t$ / ha was obtained compared to barley yield of $0.30 t /$ ha. In 2010, the Slavyanka variety was sown on 175 hectares, formed a grain yield of $1.35 \mathrm{t} / \mathrm{ha}$, as for barley yield, it was $0.2 \mathrm{t} / \mathrm{ha}$. Slavyanka variety was planted in 2009 on 20 hectares in "Chance" farm of Borsky district, in 2010 - on 30 hectares. We received grain yields of $1.43 t /$ ha in 2009 and $1.24 t$ / ha in 2010 , compared to an average barley yield of 0.97 and $0.52 t /$ ha, respectively. Slavyanka variety was sown in 2013 on the area of 700 hectares on 'Progress' farm of Bogatovsky district. The grain yield was $-1.52 \mathrm{t} / \mathrm{ha}$ with an average yield of barley in the farm of $0.50 \mathrm{t} / \mathrm{ha}$. In 2016, the sorghum variety Ros was sown in "KFKh Kamanin N.M." in Neftegorsky district on 100 hectares. The grain yield was $2.0 \mathrm{t} / \mathrm{ha}$, with an average yield of barley on the farm of $1.7 \mathrm{t} / \mathrm{ha}$. The yield of sorghum of Ros variety (1100 hectares) was $1.3 \mathrm{t} / \mathrm{ha}$, barley - $0.9 \mathrm{t}$ / ha in "Agricultural Production Cooperative named after Lenin " in Belyavsky District in the same year. We believe that the introduction of grain sorghum in production will allow to consistently receive feed grain in any arid and extremely arid weather conditions.

Bibliography

1. Grain sorghum - crop yield stabilizer in the arid zone of the Middle Volga / A.K. Antimonov, L.F. Syrkina, O.N. Antimonova, E.V. Matvienko, V.Ya. Gavrilina //Scientific support of plant selection and seed production in the Volga region. Materials of the All-Russian scientific-practical conference. - Samara, 2013. - $p$. 66-70.

2. Rumyantsev, A.V. Sorghum in solving the problem of drought and economic stability of agriculture in the conditions of the Volga region and the Urals / A.V. Rumyantsev, V.V. Glukhovtsev // Izvestiya of Orenburg State Agrarian University. - 2014. - № 2 (46). - P. 46-49.

3. Gorbunov, V.S. Sorghum is a universal feed and technical culture of the dry steppes and semi-deserts of the Russian Federation / V.S. Gorbunov, A.G. Ishin, G.I. Kostina. - Saratov, 2008. - 66 p.

3. Shepel, N.A. Selection and seed selection of hybrid sorghum / N.A. Shepel-Rostov-on-Don: RSU Publishing House, $1985 .-256$ p.

4. Bolshakov Alexander Zakharovich. Agroecological substantiation of cultivation and use of sorghum in the Central Black Soil region of the Russian Federation: author's abstract of dissertation of Candidate of Agriculture: 06.01.09/A.Z. Bolshakov. - Voronezh, 2003. - 20 p.

5. Vornikov, D.V. Formation of agrophytocenosis of field crops in the steppe zone of the Middle Volga/D.V. Vornikov, G.I. Bazdyrev, A.A. Pavlikov //Izvestiya of TAA. - 2010. - №6. - P. 7-10.

6. Stapf, O. Sorghum / O. Stapf // in: Flora of Tropical Africa. London. - 1917. -V. 9. - P. 104-154.

7. Eastin, I.D. Water and temperature effects on sorghum and millet as related to grain production and breeding. Annu. Rep. - Sorghum-millet collaborative research support program. - 1988. - P.48-54.

8. Morozov, E.V. Adaptive cultivation technology - the key to expanding grain sorghum in the Volga region / E.V. Morozov, A.I. Zavarzin, Yu.I. Sumimov // Modern technologies of cultivation of agricultural crops: a collection of scientific articles of SSAU named after N.I. Vavilov. - Saratov: Publishing House of SSAU named after N.I. Vavilov, 2003. - P. 154-159.

9. Bilenko, P.Ya. Sorghum in single-species and mixed crops / P.Ya. Bilenko, Ya. Shevnikov // Feed production. - 1985. - No 12. - P. 30-31.

10. Morozov, E.V. Economic importance of sorghum crops / E.V. Morozov, A.G. Subbotin, N.N. Safonova //Agricultural conferences. - 2017. - No 1. - P. 30-32.

11. Alabushev, A.V. Grain sorghum is a promising raw material for starch production / A.V. Alabushev, V.V. Kovtunov, O.A. Lushpina // Achievements of science and technology of agrarian and industrial complex. - 2016. - Vol. 30, No. 7. - P. 64-66.

12. Tsarev, A.P. New varieties of sorghum - an additional reserve for obtaining feed grain and cereals in the Volga region / A.P. Tsarev, G.I. Kostina, T.G. Khuspyatdinova // Corn and sorghum. - 2001. - №1. - P. 20-21.

13. Sorghum in the feeding of animals and birds / N.A. Kovtunova, V.V. Kovtunov, S.I. Gorpinichenko, G.M. Ermolina // Farmer. Volga region. - 2017. - No 4 (57). - P. 51-53.

14. Grain sorghum of Ros variety in the rations of animals and poultry / V.S. Zoteev, G.A. Simonov, S.V. Zoteev, A.G. Simonov, V.S. Nikulnikov // Effective animal breeding. - 2017. - No. 9 (139). - P. 28-30.

15. Grain sorghum in compound feeds for broiler chickens / S.V. Zoteev, V.S. Zoteev, G.A. Simonov, V.V. Mukhranov // Poultry. - 2017. - No 6. - P. 27-29. 